\title{
Hanford and the Tri-Cities Economy
}

\section{FY 1997}

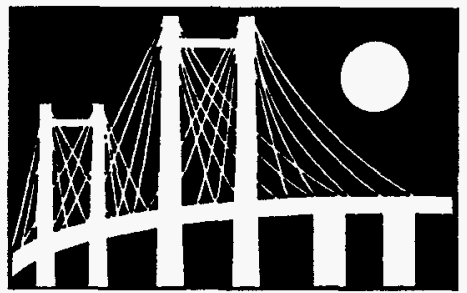

Published April 1998

U.S. Department of Energy, Richland Operations

Richland, Washington

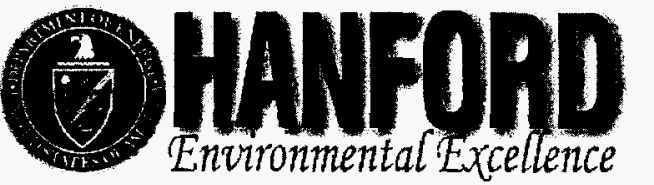




\section{RELEASE AUTHORIZATION}

\section{Document Number: DOE/RL-98-29}

Document Title:

Hanford and the Tri-Cities Economy

FY 1997

This document, reviewed in accordance with DOE Order 1430.1D, "Scientific and Technical Information Management," and DOE G 1430.1D-1, "Guide to the Management of Scientific and Technical Information," does not contain classified or sensitive unclassified information and is:

\section{APPROVED FOR PUBLIC RELEASE}
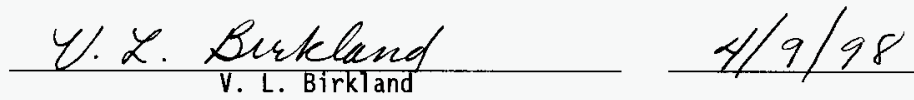

Lockheed Martin Services, Inc.

Document Control/Information Clearance

Reviewed for Applied Technology, Business Sensitivo, Classified, Copyrighted, Export Controlled, Patent, Personal/Privato, Proprietary. Protected CRADA, Trademark, Unclassified Controlled Nuclear Information.

Trademark Disclaimer. Reference herein to any specific commercial product, process, or service by trade name, trademark, manufacturer, or othemwise, does not necessarily constitute or imply its endorsement, recommendation, or favoring by the United States Govermment or any agency thereof or its contractors or subcontractors. The views and opinions of authors expressed herein do not necess arily state or reflect those of the United States Government or any agency thereof. This report has been reproduced from the best available copy. Printed in the United States of America. 


\section{Report message}

For more than 50 years, Department of Energy activities at the Hanford Site have been a major factor in the economic growth in Benton and Franklin Counties in Washington. In Fiscal Year 1997, work at Hanford directly and indirectly comprised more than 30,000 jobs in this region and nearly $\$ 1.5$ billion in local wage income. While Hanford continues to be a major economic factor, Department of Energy funding is projected to continue to decline as Hanford cleanup activities progress toward completion. Tri-Cities business and community leaders recognized this trend in lower federal budgets and responded with aggressive efforts to diversify the local economy.

This report, Hanford and the Tri-Cities Economy, FY 1997, provides a detailed assessment of the economic impacts of Hanford within the overall economic portrait of the Tri-Cities, and the community's progress to date with economic diversification efforts. The very positive message in this report is that new jobs are being created. The Department of Energy is pleased to have contributed to this success and will continue to partner with the community in diversification efforts. 


\section{Hanford and the Tri-Cities Economy FY 1997}

U.S. Department of Energy Richland Operations 


\section{At a Glance: Hanford's Role in the Tri-Cities Economy}

- The U.S. Department of Energy (DOE) and its contractors continue to have the most significant impact of any entity on the Tri-Cities economy. In fiscal year (FY) 1997, Hanford's payrolls and local purchases of goods and services contributed about $\$ 774$ million to the local economy. Through direct Hanford employment or indirect jobs stemming from Hanford work, DOE's FY 1997 budget of $\$ 1.7$ billion accounted for about $36 \%$ of all local employment and up to $67 \%$ of local wage income.

- DOE budget reductions in FY 1998 are expected to result in a net loss of about 850 Hanford jobs relative to the FY 1997 average, or about 400 additional jobs lost relative to September 1997. As a result of Hanford budget reductions, FY 1998 would see community-wide employment lowered by 1,880 jobs and wages lowered by $\$ 79$ million. This additional job loss would be teflected in services such as retail trade, construction, repair services, and real estate.

- The good news is that this downturn in jobs and income is being offset by strong economic diversification efforts by DOE, its contractors, and community organizations. In addition, business sectors such as agriculture, manufacturing, new enterprises, and regional services are expected to increase in FY 1998. This growth, offset against the economic downtum at Hanford, is expected to result in a net balance of an additional 670 jobs and a net wage gain of about $\$ 7$ million.

- DOE and its contractors have played a significant role in economic diversification by providing economic transition funding and in-kind assistance. Examples include support of facilities for business startups and technology commercialization; assistance for new businesses; transfer of equipment to municipal, commercial, and educational organizations; privatization of Hanford activities; support of staff entrepreneurial programs; and partnerships with investors to encourage outside industries to locate to the community.

- In cooperation with DOE and also independently, the Tri-City Industrial Development Council and $\mathbf{4 2}$ local organizations have contributed significantly to community economic diversification. The fruits of these combined business recruitment and development efforts paid off in FY 1997 with about 1,220 new jobs and $\$ 52$ million in wages. In FY 1998, continuing economic development activities by all organizations are estimated to result in an additional 1,440 jobs and about $\$ 55$ million in income. These increases, when added to expected expansions in agriculture and regional services, and balanced against the Hanford-related economic losses, result in a net increase of jobs and wages, as noted above. 


\section{Contents}

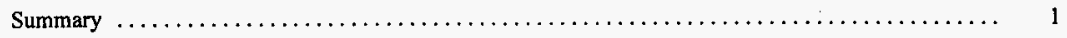

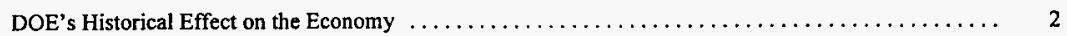

Overview of DOE Budget, Employment, and Spending $\ldots \ldots \ldots \ldots \ldots \ldots \ldots \ldots \ldots \ldots \ldots \ldots \ldots$

Effects of Payrolls and Procurements $\ldots \ldots \ldots \ldots \ldots \ldots \ldots \ldots \ldots \ldots \ldots \ldots \ldots \ldots \ldots \ldots \ldots \ldots \ldots \ldots \ldots$

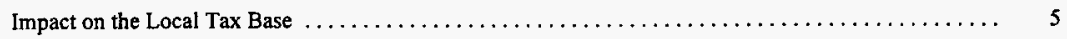

Population, Schools, Public Services, and Infrastructure $\ldots \ldots \ldots \ldots \ldots \ldots \ldots \ldots \ldots \ldots \ldots \ldots$

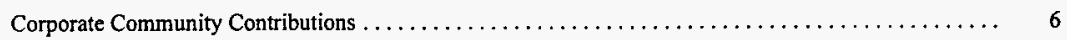

Hanford and the Tri-Cities Economic Prospects in FY $1998 \ldots \ldots \ldots \ldots \ldots \ldots \ldots \ldots \ldots \ldots \ldots$

Local Economic Development $\ldots \ldots \ldots \ldots \ldots \ldots \ldots \ldots \ldots \ldots \ldots \ldots \ldots \ldots \ldots \ldots \ldots \ldots \ldots \ldots \ldots$

DOE/RL and Contractor Economic Transition Programs $\ldots \ldots \ldots \ldots \ldots \ldots \ldots \ldots \ldots \ldots \ldots \ldots \ldots$

User Facilities and New Science and Technology Missions $\ldots \ldots \ldots \ldots \ldots \ldots \ldots \ldots \ldots \ldots \ldots \ldots \ldots \ldots$

Tri-Cities Non-Hanford Business Recruitment and Development Efforts, FY $1997 \ldots \ldots \ldots \ldots \ldots \ldots \ldots$

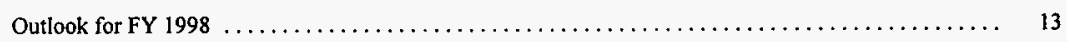

Conclusion and Looking Ahead to FY 1999 and Beyond $\ldots \ldots \ldots \ldots \ldots \ldots \ldots \ldots \ldots \ldots \ldots$ 


\section{Figures}

1 Hanford Site and Surrounding Region $\ldots \ldots \ldots \ldots \ldots \ldots \ldots \ldots \ldots \ldots \ldots \ldots \ldots \ldots \ldots \ldots \ldots \ldots, 1$

2 Total Tri-Cities Non-Agricultural Employment vs. Employment in Key Sectors $\ldots \ldots \ldots \ldots \ldots \ldots$

3 DOE/RL Contractor Procurements in Tri-Cities by Selling Industry, FY $1997 \ldots \ldots \ldots \ldots \ldots \ldots .4$

4 Three-Month Moving Averages of Tri-Cities Housing Activity $\ldots \ldots \ldots \ldots \ldots \ldots \ldots \ldots \ldots \ldots$

\section{Tables}

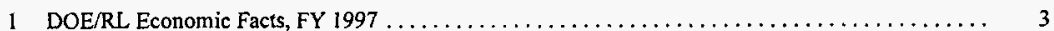

$2 \mathrm{DOE} / \mathrm{RL}$ and its Contractors are the Largest Element in the Tri-Cities' Economic Base $\ldots \ldots \ldots \ldots \quad 4$

3 DOE Payments in Lieu of Taxes and Contractor and Employee Tax Payments to Local

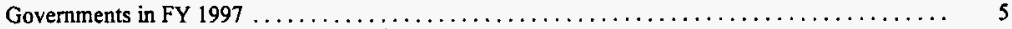

4 Population, Schools, Public Services, and Infrastructure $\ldots \ldots \ldots \ldots \ldots \ldots \ldots \ldots \ldots \ldots \ldots$

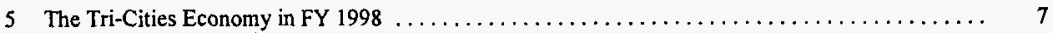

6 Selected Statistics for DOE/RL and Contractor Economic Transition Programs, FY $1997 \ldots \ldots \ldots . \quad 9$

7 User Facilities and New Science, Technology, and Training Missions $\ldots \ldots \ldots \ldots \ldots \ldots \ldots \ldots, 12$

8 Tri-Cities Non-Hanford Business Recruiting and Development Statistics, FY $1997 \ldots \ldots \ldots \ldots \ldots \quad 13$ 


\section{Hanford and the Tri-Cities Economy FY 1997}

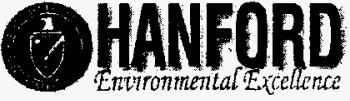

The Hanford economic region is centered on Benton and Franklin Counties (shaded area).

\section{Summary}

The missions of the U.S. Department of Energy's Richland Operations Office (DOE/RL) are to safely manage the Hanford Site, to manage and clean up its legacy wastes, and to develop and deploy new science and technology in the environmental and energy fields. Collectively, DOE/RL and its contractors are the most important single entity in the Tri-Cities local economy (Pasco, Kennewick, and Richland, Washington, and the surrounding area). While the relevant economic region affected by DOE/RL and its contractors actually embraces a geographic area reaching from Yakima in the west to Walla Walla in the east and from Moses Lake in the north to Pendleton, Oregon, in the south, over $90 \%$ of economic impacts likely occur in Benton and Franklin Counties. These two counties are defined as the "local" TriCities economy for purposes of this study. (See Figure 1.)

In the Federal fiscal year (FY) 1997 (October 1, 1996 through September 30, 1997), the total impact of DOE's local \$1.7 billion budget was felt through payrolls and local purchases of goods and services that totaled about $\$ 774$ million. Directly or indirectly, the DOE/RL budget sustained an estimated $36 \%$ of all local employment $(30,300$ out of 84,800 jobs $)$ and up to $67 \%$ of local wage income

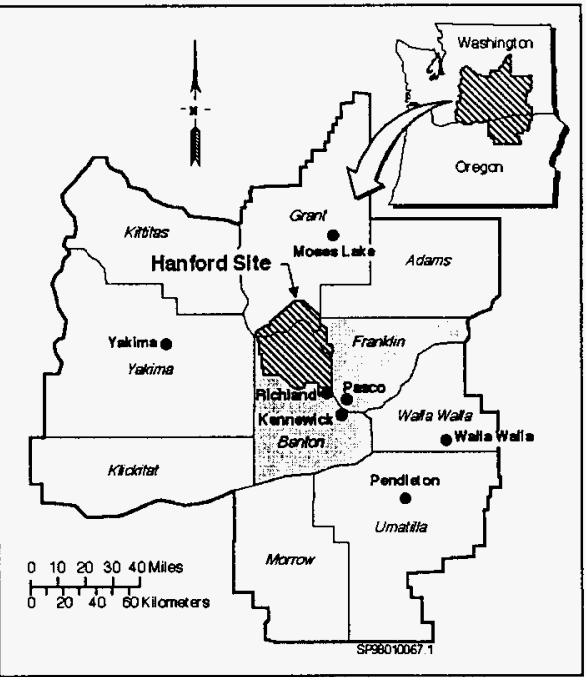

Figure 1. Hanford Site and Surrounding Region 
( $\$ 1.49$ billion out of $\$ 2.24$ billion). DOE budget reductions in FY 1998 are expected to result in a net loss of about 400 local DOE contractor jobs relative to the September 30, 1997 level, or about 850 relative to the FY 1997 average. For the community as a whole, the budget reductions would mean a loss of about 1,880 jobs and about $\$ 79$ million in wage income relative to the FY 1997 average. Fortunately, economic diversification has largely offset the impact of the local DOE losses in FY 1997 and is expected to play a large role again in FY 1998, offsetting 1,440 of the lost jobs and at least $\$ 55$ million of the lost income. Growth in agriculture and regional services is expected to more than make up the remainder of the difference, leading to net increase of 670 jobs and $\$ 7$ million in wage income.

\section{DOE's Historical Effect on the Economy}

Ever since the early 1940s, the economy of Benton and Franklin Counties in the state of Washington has been highly dependent on the level of activity at DOE contractors operating the Hanford Nuclear Reservation (otherwise known as the Hanford Site) and the nearby Pacific Northwest National Laboratory. For example, Figure 2 shows that nonagricultural employment since 1970 has closely mirrored DOE contractor employment except in the late 1970s and early 1980s, when nuclear power plant construction also was a significant factor.

With the end of the Cold War, the primary mission of the Hanford Site changed from one of production of nuclear materials for the Nation's defense program to one of environmental cleanup and restoration. To better serve this new mission, in $1996 \mathrm{DOE} / \mathrm{RL}$ restructured the manner in which much of the work is accomplished at Hanford, replacing the main management and operations (M\&O) contract with a Project Hanford Management Contract (PHMC) that integrates a larger group of specialty firms under the general management of an integrating

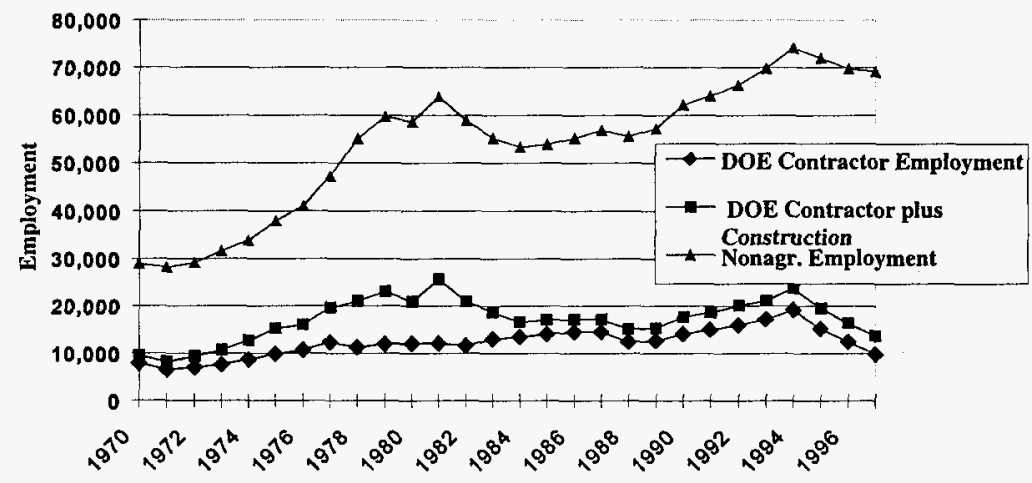

Figure 2. Total Tri-Cities Non-Agricultural Employment vs. Employment in Key Sectors 
Table 1. DOE/RL Economic Facts, FY 1997

\begin{tabular}{|l|r|}
\hline \multicolumn{2}{|l|}{ FY 1997 Budget Authority (Million S) } \\
\hline Environmental Activities & $\$ 1,265$ \\
\hline Energy R\&D & 117 \\
\hline Defense Activities & 96 \\
\hline Other & 224 \\
\hline Total FY 1997 Budget & $\$ 1,705$ \\
\hline Total FY 1997 Spending & $\$ 1,586$ \\
\hline Employ ment (Annual Average) \\
\hline Federal & 540 \\
\hline Contractors & 10,600 \\
\hline Spending (Million S) & $\$ 537$ \\
\hline Payroll & $\$ 62.7$ \\
\hline Local Procurements & $\$ 174$ \\
\hline Spending at Enterprise Companies & \\
\hline
\end{tabular}

contractor. This change already has significantly changed the balance between Site employment and procurements, altering Hanford's role in the regional economy. As the Hanford Site completes its environmental mission over the next few years, the level of activity at Hanford is expected to decline significantly. Consequently, the local community in Benton and Franklin Counties has begun a process of diversification on several fronts to reduce the region's dependency on the Hanford Site and to replace the declining Hanford portion of the area's economic base.

Many organizations and individuals are interested both in the current impact of DOE/RL and its contractors on the Tri-Cities economy and in the progress of these local economic diversification efforts. This report provides a comprehensive view of the economic role of DOE/RL and its contractors in the Tri-Cities economy during FY 1997 and discusses the impact of the diversification efforts to date.

\section{Overview of DOE Budget, Employment, and Spending} The government authorized spending of about $\$ 1.7$ billion at Hanford and Pacific Northwest National Laboratory (PNNL) in FY 1997 (Table 1). This was slightly lower than the total of $\$ 1.8$ billion in FY 1996 and continued a downward trend in Hanford Site funding that last peaked in FY 1994 and FY 1995, when the total local DOE budget was $\$ 1.9$ billion. About two-thirds of the FY 1997 budget was spent for environmental remediation activities, while the second biggest component, "other", mainly reflects the numerous and diverse science and technological development projects at Pacific Northwest National Laboratory.

DOE/RL employed an average of 540 Federal employees and 10,600 contractor employees during FY 1997. By year end, contractor employment had fallen to 10,150 . In FY 1996, average contractor employment was 11,400 , down considerably from the peak of 19,200 in FY 1994. However, the drop between FY 1996 and FY 1997 reflects not only employment declines, but also reorganization of the contractors under the PHMC. Under the PHMC, almost 2,200 employees of the former $\mathrm{M} \& \mathrm{O}$ contractor were moved into six "enterprise companies," (ENCOs) and ceased to be counted as "inside the fence" (that is, as Hanford employees). The idea was that by the end of two years these companies would be able to competitively capture and perform both Hanford and non-Hanford work. During FY 1997 the vast majority of these workers (more than $90 \%$ ) were performing work for the Hanford Site. By the end of FY 1997, nearly 100 jobs at the enterprise companies were non-Hanford jobs. In addition, 137 non-Hanford jobs were created in other companies in the area with the assistance of the PHMC team.

The DOE budget affects the local economy both through purchases of goods and services by DOE/RL and its contractors and through spending of payroll dollars by their employees. For example, in FY 1997 the DOE/RL contractors spent almost $\$ 63$ million on procurements in 
Table 2. DOE/RL and its Contractors are the Largest Element in the TriCities' Economic Base

\begin{tabular}{|l|c|}
\hline \multicolumn{2}{|c|}{ Total Impacts, FY 1997* } \\
\hline $\begin{array}{l}\text { Impact of Contractor } \\
\text { Payrolls on Tri-Cities } \\
\text { Employment }\end{array}$ & $2 \mathrm{l}, 600$ jobs \\
\hline $\begin{array}{l}\text { Impact of Contractor Pay- } \\
\text { rolls on Tri-Cities Income }\end{array}$ & $\$ 1,042$ million \\
\hline $\begin{array}{l}\text { Impact of Procurements and } \\
\text { Payments to ENCOs on } \\
\text { Total Tri-Cities Employment }\end{array}$ & 8,700 jobs \\
\hline $\begin{array}{l}\text { Impact of Hanford Procure- } \\
\text { ments and ENCO Payments } \\
\text { on Total Tri-Cities Income }\end{array}$ & $\$ 449$ million \\
\hline $\begin{array}{l}\text { Note: Includes direct jobs and payroll. Total } \\
\text { jobs in the economy }=84,800 \\
\text { Total wage income }=\$ 2.24 \mathrm{~B}\end{array}$ \\
\hline
\end{tabular}

the Tri-Cities. Of this amount roughly $65 \%$ was for various business services, $25 \%$ for trade, and about $5 \%$ for construction (Figure 3 ). This contrasts with about $\$ 99$ mil]ion spent in the Tri-Cities in FY 1996. However, the DOE/RL contractors also bought $\$ 174$ million worth of services from the new enterprise companies during FY 1997, as well as certain additional services such as travel that were subcontracted locally. Thus, despite the apparent employment decline from FY 1996 to FY 1997, the change in total economic activity at Hanford between FY 1996 and FY 1997 was actually quite small. The Tri -Cities captured about $31 \%$ of all DOE/RL contractor procurements in 1997, vs. $17-18 \%$ in FY 1996 . The contractor payroll cost in FY 1997 was about $\$ 682$ million in FY 1997 ( $\$ 537$ million in wages, the rest in benefits and other payroll costs), a decline from $\$ 878$ million in FY 1996. The change mainly reflects the redefinition of "inside the fence" employment as employees were moved to the enterprise companies.

\section{Effects of Payrolls and Procurements}

Even after recent downsizing, the Hanford Site was still the largest single source of employment in the Tri-Cities at the end of September 1997 , with 10,150 direct employees. The number employed is the smallest since 1976, but still represents roughly one job in seven in the economy and directly represents about $30 \%$ of the total wage income in the area. Direct procurements plus subcontracts by the DOE contractors represented about $4-5 \%$ of the total sales in the Tri-Cities economy during FY 1996 and about 11-12\% in FY 1997.

PNNL has taken responsibility for providing both assessments and forecasts of the Tri Cities economy for more than 15 years. The PNNL model of the Tri-Cities economy calculates the impact of Hanford payrolls and other spending. In FY 1997 the model shows that about 21,600 total Tri-Cities jobs were supported directly or indirectly by the Hanford payroll and about 8,700 by procurements and the ENCO contracts, for a total of 30,300 (Table 2). This represents $36 \%$

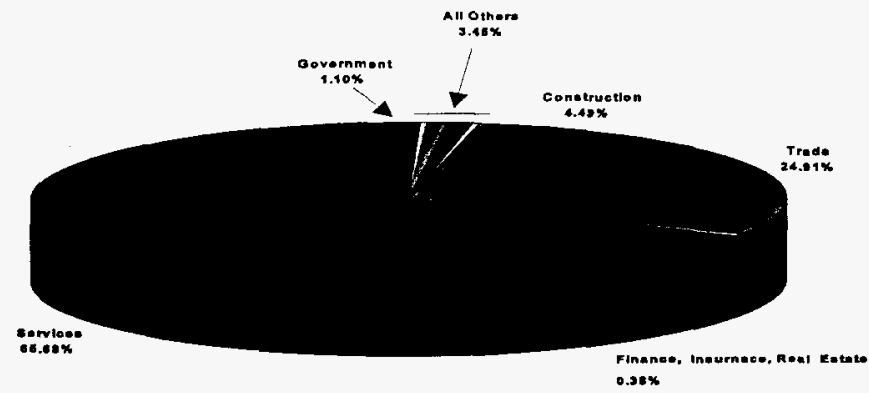

Figure 3. DOE/RL Contractor Procurements in Tri-Cities by Selling Industry, FY 1997 
Table 3. DOE Payments in Lieu of Taxes and Contractor and Employee Tax Payments to Local Governments in FY 1997

\begin{tabular}{|l|l|}
\hline \multicolumn{1}{|c|}{ Source } & \multicolumn{1}{c|}{ Amount } \\
\hline $\begin{array}{l}\text { Payments to Schools and } \\
\text { Payments in Lieu of Taxes }\end{array}$ & $\$ 2.7$ million \\
\hline $\begin{array}{l}\text { Contractor Sales and Use } \\
\text { Taxes }\end{array}$ & $\$ 0.9$ million \\
\hline $\begin{array}{l}\text { Contractor Property and } \\
\text { Leasehold Taxes }\end{array}$ & $\$ 0.6$ million \\
\hline $\begin{array}{l}\text { Employee Sales and Use } \\
\text { Taxes (Local Share) }\end{array}$ & $\$ 5.9$ million \\
\hline $\begin{array}{l}\text { Employec Property Taxes } \\
\text { (Local Share) }\end{array}$ & $\$ 35.1$ million \\
\hline
\end{tabular}

Table 4. Population, Schools, Public Services, and Infrastructure

\begin{tabular}{|c|c|}
\hline Economic Factor & Value \\
\hline $\begin{array}{l}\text { Total Population, } \\
\text { Benton and Franklin } \\
\text { Counties }\end{array}$ & $\begin{array}{l}1994-169,900 \\
1995-175,000 \\
1996-174,700 \\
1997-177,900\end{array}$ \\
\hline $\begin{array}{l}\text { Head Count School } \\
\text { Enrollment, Benton and } \\
\text { Franklin Counties }\end{array}$ & $\begin{array}{l}1994-37,073 \\
1995-37,549 \\
1996-38,180 \\
1997-38,541\end{array}$ \\
\hline $\begin{array}{l}\text { Recent Average Housing } \\
\text { Values by Fiscal Year }\end{array}$ & $\begin{array}{l}1994-\$ 119,200 \\
1995-\$ 112,700 \\
1996-\$ 109,500 \\
1997-\$ 115,300\end{array}$ \\
\hline $\begin{array}{l}\text { Housing Starts by Fiscal } \\
\text { Year }\end{array}$ & $\begin{array}{lr}1994- & 1,117 \\
1995- & 433 \\
1996- & 667 \\
1997- & 557\end{array}$ \\
\hline $\begin{array}{l}\text { 4th Quarter Apartment } \\
\text { Vacancies, Tri- Cities, by } \\
\text { Fiscal Year }\end{array}$ & $\begin{array}{l}1994-5.0 \% \\
1995-11.5 \% \\
1996-18.0 \% \\
1997-12.0 \%\end{array}$ \\
\hline
\end{tabular}

of the jobs in the economy. Fully $67 \%$ of the wage income in the economy may depend directly or indirectly on Hanford payrolls and procurements.

\section{Impact on the Local Tax Base}

The DOE contractors mainly conduct work for the Federal government in facilities owned by the Federal government. This work generally is not subject to Washington State sales taxes, nor are the Federal facilities on the tax rolls. Instead, the Federal government makes payments of schools impact funds and payments in lieu of taxes (PILT) to local governments and taxing districts. In FY 1997 the Federal government disbursed a total of $\$ 2.7$ million (Table 3). The contractors paid \$0.9 million in local sales and use taxes (use taxes are paid on use of selected equipment instead of the sales tax), as well as $\$ 0.5$ million property taxes on their own property (e.g., Battelle, which operates PNNL, owns \$38 million worth of its own facilities in North Richland), \$0.1 million in leasehold taxes, Washington State Business and Occupations Tax, and some portion of taxes paid on rental facilities owned by private companies. (Data are not readily available on these items.) Finally, based on their incomes, the employees of DOE and the contractors paid an estimated $\$ 5.9$ million in sales taxes and an estimated \$35.1 million in property taxes. In all, direct Hanfordrelated taxes in FY 1997 represented about $27 \%$ of sales and use taxes in Benton and Franklin counties and about $18 \%$ of total property tax collections.

\section{Population, Schools, Public Services, and Infrastructure}

Historically, changes in employment at Hanford have been one of the major drivers of change in the population of Benton and Franklin Counties. In 1994-1997, however, it appears that there has been a change in this historical relationship. Despite the loss of some 9,000 positions at Hanford (from 19,200 in July 1994 to under 10,150 by September 1997), and a corresponding decline of 6,000 in total nonagricultural employment $(75,500$ in September 1994 to 69,200 in September 1997), population in the area has actually risen (Table 4). The demographers at the State of Washington Office of Financial Management estimate that the population of Benton and Franklin Counties increased from 169,900 in 1994 to 178,000 in 1997 . The reasons for this increase are not clear. The increase in population also is reflected in the school-age population for the 10 local school districts in the two-county area.

The accompanying chart of Tri-Cities housing prices for the last ten years (Figure 4) shows the strong effect that changes at the Hanford Site had on the real estate market during that time, especially 19891994 (3-month averages are used to smooth month-to-month volatility). Beginning with the start of downsizing in July 1994, prices initially declined, but then appeared to recover and then stabilize.

Table 4 data on housing starts show that there was considerable falloff in construction from 1994 to 1995; but construction then recovered 


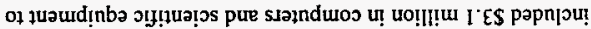

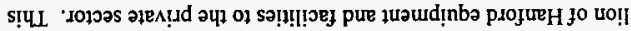

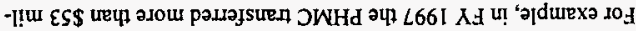

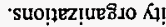

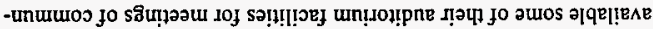

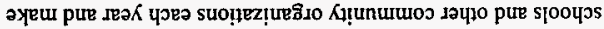

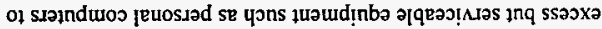

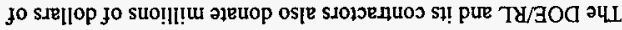

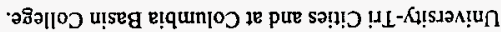

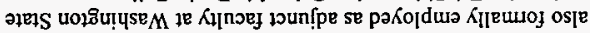

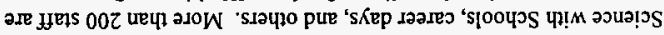

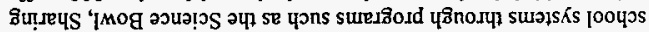
[ह०O| әч|

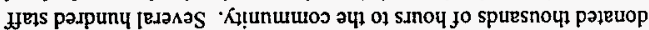

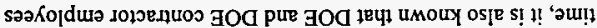

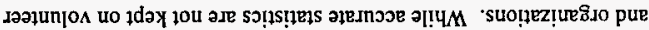

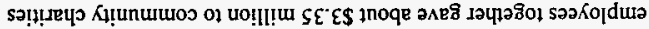

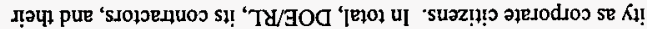

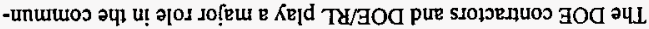

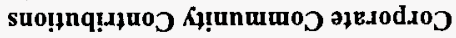

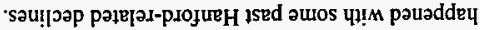

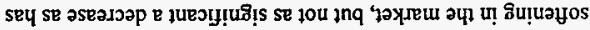

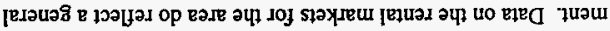

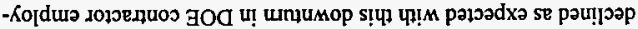

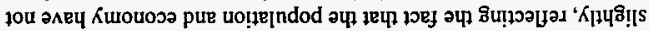

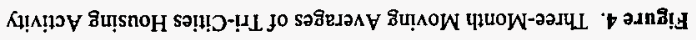

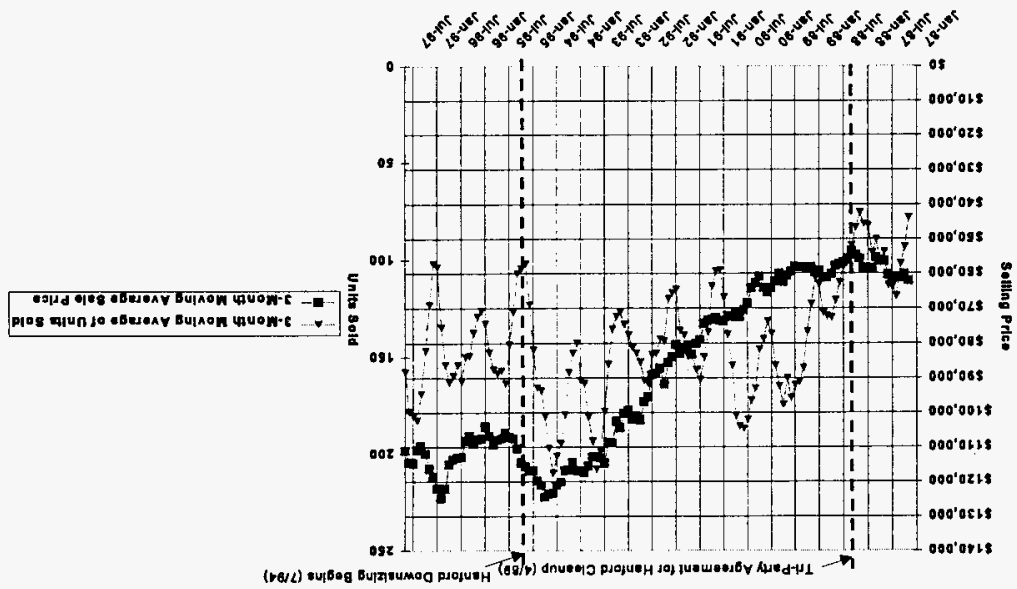

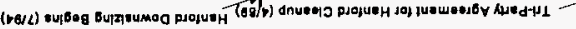


Table 5. The Tri-Cities Economy in FY 1998 (Projected)

\begin{tabular}{|c|c|}
\hline Economic Factor & Value \\
\hline \multicolumn{2}{|l|}{ DOE/RL } \\
\hline Budget & $\$ 1,523$ million \\
\hline Contractor Employment & 9,740 \\
\hline Local Procurements & $\$ 58$ miltion \\
\hline Local Subcontracts & $\$ 162$ million \\
\hline \multicolumn{2}{|c|}{ Direct plus Indirect Impacts on the Economy } \\
\hline \multirow{2}{*}{$\begin{array}{l}\text { Total Community Impact } \\
\text { (DOE/RL, Contractors, } \\
\text { and General Economy) }\end{array}$} & $-1,880$ total jobs \\
\hline & $\begin{array}{l}-\$ 79 \text { million wage } \\
\text { Income }\end{array}$ \\
\hline \multicolumn{2}{|c|}{ Other Sectors' Impacts on the Economy } \\
\hline \multirow[t]{2}{*}{ Agriculture } & +680 total jobs \\
\hline & $\begin{array}{l}+\$ 14.1 \text { million } \\
\text { wage income }\end{array}$ \\
\hline $\begin{array}{l}\text { Manufacturing (Tradi- } \\
\text { tional Major Employers) }\end{array}$ & No change \\
\hline \multirow[t]{2}{*}{ Regional Services } & +425 total jobs \\
\hline & $\begin{array}{l}+\$ 16.2 \text { million } \\
\text { wage income }\end{array}$ \\
\hline \multirow{2}{*}{$\begin{array}{l}\text { New Enterprises and } \\
\text { Expansions }\end{array}$} & $+1,440$ total jobs \\
\hline & $\begin{array}{l}+\$ 55 \text { million } \\
\text { wage income }\end{array}$ \\
\hline \multicolumn{2}{|c|}{ Total Net Impacts, All Sectors } \\
\hline Employment & +670 jobs \\
\hline Payroll & $\begin{array}{l}+\$ 7 \text { million wage } \\
\text { income }\end{array}$ \\
\hline
\end{tabular}

regional schools, $\$ 75,000$ in laboratory analytical equipment to a private educational lab program, and 80 pieces of equipment to 14 TriCities businesses to promote local job creation.

\section{Hanford and the Tri-Cities Economic Prospects in FY 1998}

The Hanford Site is still very much in transition, stemming from changes in management approach and downsizing in its workforce.

Fiscal Year 1998 promises some additional reductions in budget with associated further reductions in workforce (Table 5). Overall, the expected local FY 1998 DOE budget of approximately $\$ 1.5$ billion (which includes $\$ 115$ million set aside for privatization of the Hanford Site's high-level nuclear waste operations and will not be used to fund current projects) should sustain a contractor workforce of more than 9,700 and local procurements and subcontracts of about $\$ 220$ million, if current employment and procurement patterns hold. This would mean a loss of about 400 additional contractor workers relative to September 1997 or about 850 relative to the FY 1997 average, a loss of $\$ 23$ million in payroll dollars, and a reduction of $\$ 17$ million in local procurements and subcontracts. For the community as a whole, other things equal, the impact would be to lower FY 1998 employment in the whole community (including Hanford) by 1,880 jobs and wage income by $\$ 79$ million relative to the FY 1997 average.

Increasing contributions from other sectors are expected to more than make up the loss. The other large, traditional employers of the TriCities, the region's farm economy, and some new enterprises continue to have a significant impact on growth in the two-county region independent of the Hanford Site.

Agriculture. The outlook for the region's major crops is mixed, compared with 1997, but an increase of $6 \%$ in Benton-Franklin County farm proprietor and labor income to about $\$ 123$ million appears possible, even though it will still be well below the record of $\$ 192$ million in 1995. Soft white wheat prices are expected to be flat as a result of relatively high stocks and reduced domestic use, coupled with difficulties in Asian markets and strengthening of the dollar versus Asian currencies. Potato prices are expected to be in the range of $\$ 5.50 \notin 25$ cents. The smaller $1997-98$ crop originally was expected to boost prices early in the year, but Canadian competition is pushing prices downward. The hay market looks more solid than in 1997. Milk prices are expected to increase moderately, but the higher hay prices are also expected to increase some producers' costs. Processed vegetable prices are expected to be mixed. Apple production in the Northwest and nationwide is expected to be down from 1997, which is expected to strengthen prices. Tree fruit returns may be as much as $15 \%$ better than in 1997 . A major source of uncertainty in apple markets is access to the Mexican market because of high tariffs and the Asian markets because of their currency devaluations, emerging recessions, and lender-imposed austerity programs. Beef production is exected to be down about $5 \%$ from last year's levels, and exports 
are expected to increase 6-10\%. Grass seed production and prices are expected to be strong. Both Concord grapes and wine grapes are expected to maintain strong prices despite big harvests in 1997. A significant feature of the local markets is increased vegetable processing capability, which has expanded significantly in the last five years.

Traditional Major Employers. Many of the Tri Cities' traditional major employers expect to experience constant-to-slightly declining employment and sales. This includes Washington Public Power Supply System, which expects to produce about the same level of power for the next five years with 200 fewer employees $(1,100$ down to 900 by the year 2000); Siemens, with constant employment at about 700 employees; Lamb Weston, with a constant level of 3,000 employees at all of their Columbia Basin facilities; Sandvik, constant at about 275 employees; and Iowa Beef Processors in western Walla Walla County, constant at about 1,500 employees. Depending on agricultural product prices, regional manufacturing exports should stay approximately constant at $\$ 1.0$ billion. The exception in the traditional major employer group appears to be Burlington Northern Railroad, which currently employs about 700 workers in the area and is expecting to continue a recent positive hiring trend. Earnings among the area's traditional major manufacturing employers are expected to be roughly constant, while transportation services should increase by about $5 \%$.

New Employers. Major non-Hanford manufacturing and service employers are also being added to the mix. In 1997 this included nonHanford activity at several of the enterprise companies, numerous small startup firms, Dakotah Direct telemarketing with 115 employees; an addition to Columbia Colstor/Lamb Weston cold storage, with 75 additional employees; Watts Brothers' corn processing facility in Paterson, with 150-plus employees (some seasonal); and Bayform Manufacturing's distribution center for window components in Pasco (3 employees). In FY 1998, the International Hearth Melting (formerly Oremet) titanium manufacturing facility in Richland (60 employees), a major expansion at Twin City Foods (90 additional jobs) and an expansion at Dakotah Direct ( 85 additional jobs) should be added to the local economic base. Precision Castparts, which makes aircraft turbine engine parts, also has committed to expand to the Tri-Cities area with between 75 and 200 employees, but expansion is currently on hold because of a down market. The Tri-Cities' Columbia Center area also continues to grow as a regional retail and service center, with the 1997 opening of superstores selling books and sporting goods and an 8-screen theater complex. New hotels were opened in Richland, Kennewick, and Pasco.

\section{Local Economic Development}

Much of the new activity is a direct result of economic development programs and business recruitment and assistance programs conducted by the Hanford contractors, by the Tri-City Industrial Development Council (TRIDEC); and by a number of the local government entities in Benton and Franklin Counties. While these groups performed 
Table 6. Selected Statistics for DOE/RL and Contractor Economic Transition Programs, FY 1997

\begin{tabular}{|c|c|}
\hline Program & Contribution \\
\hline $\begin{array}{l}\text { Economic Development } \\
\text { Grants to TRIDEC } \\
\text { (“3161" Program and } \\
\text { other closely associated } \\
\text { programs) }\end{array}$ & $\begin{array}{l}\text { \$13.8 million econ- } \\
\text { omic development } \\
\text { funds (see TRIDEC } \\
\text { in Table } 7 \text { for } \\
\text { results) }\end{array}$ \\
\hline $\begin{array}{l}\text { Facilities Reuse }(100 \text {, } \\
300,400 \text {, and } 3000 \\
\text { Areas) }\end{array}$ & $\begin{array}{l}\text { Expansion of } \\
\text { Kaiser aluminum } \\
\text { extrusion operation } \\
\text { by } 24 \text { workers } \\
\text { (potential of } \\
\text { another } 25 \text { ) }\end{array}$ \\
\hline $\begin{array}{l}\text { Agri-Business Commer- } \\
\text { cialization and Develop- } \\
\text { ment Center (ABCD) }\end{array}$ & $\begin{array}{l}\text { Five new busi- } \\
\text { nesses, technical } \\
\text { assistance: } 6 \text { new } \\
\text { product lines. } \\
\text { Recruiting: poten- } \\
\text { tial capital invest- } \\
\text { ment of about } \$ 35 \\
\text { million. Total of } \\
\text { about } 28 \text { jobs. }\end{array}$ \\
\hline Privatization & $\begin{array}{l}2,170 \text { workers to } \\
\text { Enterprise Com- } \\
\text { panies; }-100 \text { on } \\
\text { non-Hanford work }\end{array}$ \\
\hline $\begin{array}{l}\text { Hanford Contractor } \\
\text { Economic Development } \\
\text { Programs } \\
\text { Six Enterprise Com- } \\
\text { panies, } 15 \text { Other New } \\
\text { Non-Hanford Companics } \\
\text { Founded or Expanded in } \\
\text { FY } 1997\end{array}$ & $\begin{array}{l}\text { Combined, } 160 \text { new } \\
\text { non-Hanford direct } \\
\text { jobs (115 shared } \\
\text { with TRIDEC) } \\
\text { \$7.7 million } \\
\text { combined corporate } \\
\text { investment }\end{array}$ \\
\hline $\begin{array}{l}\text { PNNL Economic } \\
\text { Development Office }\end{array}$ & $\begin{array}{l}10 \text { new non- } \\
\text { Hanford com- } \\
\text { panies; } 23 \text { new non- } \\
\text { Hanford direct jobs }\end{array}$ \\
\hline $\begin{array}{l}\text { Science and Technology } \\
\text { Park }\end{array}$ & $\begin{array}{l}\text { Included in } \\
\text { Tables } 7,8\end{array}$ \\
\hline
\end{tabular}

much of this work with their own resources, economic transition funding and in-kind assistance from the DOE has also played a critical role. In FY 1997, about 670 jobs and about $\$ 27$ million in wage income were directly added to the economic base from these sources; current commitments to expansion and expected recruitment successes are expected to add almost 820 additional jobs and $\$ 31$ million in income in FY 1998. In FY 1997, the total impact was probably about 1,220 jobs and $\$ 52$ million; in FY 1998 the total impact is expected to be 1,440 jobs and $\$ 55$ million.

\section{DOE/RL and Contractor Economic Transition}

\section{Programs}

Six business strategies have been developed under DOE/RL's Hanford Economic Transition Program to support diversification of the local economy while helping to clean up Hanford.

1. Build strategic partnerships where economic collaboration and synergy are strong.

2. Leverage (match) existing site operations, technologies and physical assets to "seed private sector business opportunities and economic growth.

3. Invest in and build around community capabilities and strengths.

4. Provide a real retum on investment in terms of cost reduction, technology infusion into cleanup, and creating business enterprises.

5. Align the Hanford Economic Transition Program with the Secretary of Energy's strategic goals, the Hanford Site mission, and local community economic development goals.

6. Strategically focus on the recruitment, expansion, and start-up of small business enterprises at Hanford.

The DOE contractors also have their own economic development programs, as summarized in Table 6. The following are examples of economic transition and privatization efforts of DOE/RL and its contractors.

Economic Development Grants. A total of $\$ 13.8$ million has been granted to TRIDEC to fund community proposals intended to help diversify the local economy. Proposals funded by TRIDEC as a result of the grant include expanding the Tri-Cities Commercialization Parthership, supporting the Agri-Business Commercialization and Development Center ( $\mathrm{ABCD}$ ), worker and community impact studies, supporting the Tri-Cities Science and Technology Park, supporting the Entrepreneur/Small Business Support Partnership, funding the Minority Business Resource Center (Columbia Basin Minority Economic Development Association), supporting the Hanford Regional Planning Commission, the Applied Process Engineering Laboratory (APEL), programs to enhance the Columbia River shore and to promote tourism, the PNNL Entrepreneurial Leave of Absence Program and Technical Assistance Program, and several other activities. 
Facilities Reuse. DOE has worked with the Port of Benton to allow the use of currently under-utilized DOE facilities in the south portion of the 400 Area of the Hanford Site as business incubator facilities as well as the former 3000 Area, which consists of approximately 72 acres of land and 13 buildings in the vicinity of North Richland. DOE/RL transferred the 3000 Area to the Port of Benton in 1996. DOE/RL transferred an extrusion press and ancillary metalworking equipment to the City of Richland under the authority of the Atomic Energy Community Act in August 1994. The City of Richland re-sold the equipment to Kaiser Aluminum, which established an extrusion division in North Richland. A second extrusion press was transferred directly to Kaiser early in FY 1998. DOE also established a Cooperative Research and Development Agreement (CRADA) with the Washington State Department of Fisheries and TRIDEC that demonstrated the viability of rearing chinook salmon for release using 100 Area facilities. Excess welding equipment was provided to Columbia Basin College's Advanced Welding Training Center.

Agri-Business Technology Commercialization and Development Center $(A B C D)$. A Memorandum of Understanding (MOU) was signed between Washington State University, PNNL, DOE, the Port of Benton, and the TRIDEC to form the Agri-Business Technology Commercialization and Development Center (ABCD). $A B C D$ is a user-based facility for companies that are interested in commercialization and technology transfer opportunities in the areas of food production, food preservation technology, food engineering, food processing waste utilization, and related bio-processing. The facility allows those companies to be involved in the development phase of that technology.

$\mathrm{ABCD}$ has been directly involved in 5 new businesses. Technical assistance provided by the center has helped establish 6 new product lines at existing companies, and has helped maintain employment at 25 other companies. In FY 1997 this activity has created or maintained an estimated 28 jobs. ABCD has also assisted in recruiting agriculturally-related manufacturing businesses with capital investment of about $\$ 35$ million and potential employment of $125-130$. The Center has nine new businesses in progress for the immediate future, is helping recruit four others, and is working on three new product lines. The potential is believed to be 200 new employees in FY 1998.

Privatization. Hanford privatization efforts date back to 1992, when the decontamination laundry services were outsourced to a commercial company. This was followed in $1995-96$ by the privatization of several of the Site's work scope elements, including geotechnical services, computerized site orientation training, mail services, the Business Resource Center (outplacement), treatment/disposal of certain wastes, the Hanford Museum, and the on-site gasoline stations. All together, this resulted in about 40 private-sector jobs.

The major outsourcing in FY 1997 under the PHMC involved the establishment of the enterprise companies on October 1, 1996, and the 
transfer of 2,169 former Hanford employees into those new businesses. The enterprise companies privatized the following scopes of work: safeguards and security (B\&W Protec: 180 employees), quality assurance services (Duke Engineering \& Services Northwest: 45 employees), architect-engineering/construction management services (Fluor Daniel Northwest: 1270 employees), telecommunications and information management (Lockheed Martin Services, Inc.: 525 employees), miscellaneous environmental and waste management services (Waste Management Northwest: 49 employees), and miscellaneous technical services (SGN Eurisys Services: 100 employees). Also, in August 1997, the glassblowing scope of work was outsourced to the former Hanford Site glassblower. An estimated 100 workers at the enterprise companies were supported by non-Hanford business at the end of FY 1997.

Hanford Contractor Economic Development Programs. The Hanford contractors have active economic development programs, which include industrial recruiting, business technical assistance, corporate investment, and venture capital. As a result of these efforts, 137 new jobs were claimed in FY 1997 at 4 new non-ENCO private firms and at several existing firms in the Tri-Cities area.

PNNL Economic Development Office (EDO). The mission of this office is to propel economic development nationally, regionally, and locally by accelerating the commercialization of technology. Tools include startup and business technical assistance, licensing of technologies, entrepreneurial leaves of absence, and partnering with other investors. The EDO's small business program provides access to staff expertise and specialized facilities of Pacific Northwest and other national laboratories. It is networked with regional university programs, and regional Small Business Administration programs. The Entrepreneurial Leave of Absence Program is a component of the Tri-City Area's Entrepreneurial Support Network (ESN) and provides incentives for PNNL staff members to become entrepreneurs while reducing the risk of starting a new venture. Technology partnerships are key to attracting outside industry and also contribute to growing existing businesses. This program is designed to create partnerships based on shared technology, both with firms outside the region that result in their relocation to the area and with larger firms that have divisions in the area and will expand their operations. EDO also oversees the ABCD and APEL. EDO's small business, entrepreneurial leave, and technology partnership programs helped establish or attract 10 new firms with 23 new jobs in FY 1997.

Science and Technology Park. The Tri-Cities Science and Technology Park is intended to be the area's center for rapid deployment of technologies and local designated user facilities. Occupants of the 2,600-acre park include the Washington State University (WSU) branch campus, PNNL, and about 60 business and technical organizations involved in life sciences, energy, advanced materials, and environmental cleanup development. 
Table 7. User Facilities and New Science, Technology, and Training Missions

\begin{tabular}{|l|l|}
\hline \multicolumn{1}{|c|}{ Activity } & $\begin{array}{c}\text { Expected Economic } \\
\text { lmpact }\end{array}$ \\
\hline $\begin{array}{l}\text { Laser Interferometer } \\
\text { Gravitational Wave } \\
\text { Observatory (LiGO) }\end{array}$ & 0 in FY 1998 \\
\hline $\begin{array}{l}\text { William R. Wiley } \\
\text { Environmental and } \\
\text { Molecular Sciences } \\
\text { Laboratory (EMSL) }\end{array}$ & $\begin{array}{l}\text { Guest researchers } \\
\text { equivalent to about 85 } \\
\text { full-time staff } \\
\text { (assumed one-half } \\
\text { already at PNNL in } \\
\text { FY 1997). }\end{array}$ \\
\hline $\begin{array}{l}\text { Applied Process } \\
\text { Engineering } \\
\text { Laboratory (APEL) }\end{array}$ & $\begin{array}{l}\text { 50 new PNNL and } \\
\text { WSU jobs and about } \\
\text { \$2.4 million in payroll } \\
\text { in FY 1998 }\end{array}$ \\
\hline $\begin{array}{l}\text { Hazardous Materials } \\
\text { Management and } \\
\text { Emergency Response } \\
\text { (HAMMER) Training }\end{array}$ & $\begin{array}{l}\text { Estimated 2,000 } \\
\text { Students, 30 perma- } \\
\text { nent staff. All staff } \\
\text { are assumed to already } \\
\text { be present in FY 1997. } \\
\text { \$8.6 million direct } \\
\text { income }\end{array}$ \\
\hline
\end{tabular}

\section{User Facilities and New Science and Technology Missions}

Table 7 shows the impact of several new user facilities at Hanford and PNNL. Combined, these facilities bring payrolls and spending equivalent to about 165 full-time employees. Ground breaking for Laser Interferometer Gravitational Wave Observatory (LIGO) took place on the Hanford Site on July 6, 1994. This $\$ 90$ million project will detect and measure gravitational waves. The facility will house approximately 25-30 permanent staff members and will host visiting scientists. LIGO is scheduled to be completed by 1999 , so it is not counted in FY 1998. LIGO is a joint project coordinated between the California Institute of Technology and the Massachusetts Institute of Technology. The National Science Foundation manages funding for the project.

PNNL's \$230-million William R. Wiley Environmental and Molecular Sciences Laboratory became operational in 1997. It serves as a national collaborative research and technology laboratory, providing educational and training opportunities for future scientists.

The Applied Process Engineering Laboratory (APEL) is a joint project with DOE, City of Richland, Port of Benton, and Washington Public Power Supply System. An existing facility is being refurbished to create a permitted, high-bay incubator that will spin off new technology-based enterprises focused on environmental remediation and pollution prevention.

The Hanford Demonstration Zone (not shown in the table since it is not really a facility) is a joint effort between DOE-RL, the state and local regulators, and site contractors to provide an approved infrastructure for the testing and demonstration of new and mature technologies applicable for site cleanup needs.

Hanford's Hazardous Materials Management and Emergency Response (HAMMER) training center trains workers how to cope with massive chemical accidents and a range of other topics. About 2,000 students are expected to be enrolled most months.

\section{Tri-Cities Non-Hanford Business Recruitment and Development Efforts, FY 1997}

DOE and TRIDEC have executed a Memorandum of Understanding (MOU) that designates TRIDEC as the "one voice" for the local community on economic development issues. The MOU allows DOE and the local community to develop, review, and prioritize economic development activities related to Hanford. TRIDEC currently represents 42 economic development entities in the Benton/Franklin County area. Several of the local governments have their own recruitment and community development programs that have resulted in the creation of additional investments and jobs beyond those claimed by and credited to DOE, DOE contractors, and TRIDEC diversification efforts. 
Table 8. Tri-Cities Non-Hanford Business Recruiting and Development Statistics, FY 1997

\begin{tabular}{|c|c|}
\hline Program or Entity & Effect \\
\hline $\begin{array}{l}\text { DOE Contractor } \\
\text { Economic Develop- } \\
\text { ment Programs, New } \\
\text { Missions, and User } \\
\text { Facilities }\end{array}$ & $\begin{array}{l}385 \text { direct, non-Hanford } \\
\text { jobs (102 shared with } \\
\text { TRIDEC programs), } \\
\text { \$20 million direct } \\
\text { income }\end{array}$ \\
\hline TRIDEC & $\begin{array}{l}\$ 75 \text { million new } \\
\text { investment ( } \$ 42 \text { million } \\
\text { shared with DOE, } \\
\text { contractor programs) } \\
345 \text { direct, non-Hanford } \\
\text { jobs in FY } 1997 \text { (115 } \\
\text { shared with DOE, } \\
\text { contractor programs) }\end{array}$ \\
\hline $\begin{array}{l}\text { Pasco Community } \\
\text { Development }\end{array}$ & $\begin{array}{l}\$ 47.2 \text { million new } \\
\text { investment ( } \$ 1 \text { million } \\
\text { shared with DOE, } \\
\text { contractors, TRIDEC) } \\
292 \text { new, non-Hanford } \\
\text { jobs, plus up to } 300 \\
\text { seasonal jobs ( } 115 \\
\text { shared with TRIDEC, } \\
\text { DOE, contractors) }\end{array}$ \\
\hline City of Richland & $\begin{array}{l}25-30 \text { jobs in plastics } \\
\text { manufacture; Inter- } \\
\text { national Hearth Melting }\end{array}$ \\
\hline Port of Benton & $\begin{array}{l}\text { About } 50 \text { jobs in food } \\
\text { freezing, light metal } \\
\text { fabrication, winery }\end{array}$ \\
\hline Port of Kennewick & $\begin{array}{l}\text { Titanium Sports; Pacific } \\
\text { Rail Car and small } \\
\text { electronics firm - total } \\
\text { of about } 60 \text { jobs }\end{array}$ \\
\hline $\begin{array}{l}\text { All Programs, } \\
\text { FY } 1997\end{array}$ & $\begin{array}{l}670 \text { direct jobs: } \$ 27 \\
\text { million direct income. } \\
1,220 \text { total jobs; } \$ 52 \\
\text { million total wage } \\
\text { income }\end{array}$ \\
\hline
\end{tabular}

Because business recruitment and development is a joint responsibility of many parties, many entities can justly claim joint credit for development successes such as Dakotah Direct or International Hearth Melting. Shared responsibilities are shown in Table 8. Combining all sources, about 670 direct jobs paying about $\$ 27$ million were created. The bottom line of the $(1,220$ total jobs and $\$ 52$.I million in wage income) is the total impact from all sources of business recruitment and development efforts, after removing all double counting implicit in shared successes.

\section{Outlook for FY 1998}

Future expansions in FY 1998 are expected to include at least 258 additional jobs at International Hearth Melting, Twin City Foods, Dakotah Direct, and Kaiser Aluminum. Hanford user facilities are expected to add about 140 non-Hanford jobs. The DOE contractors (PHMC plus PNNL) have a goal of generating at least 300 nonHanford jobs in 1998, and to helping sustain the new entities previously created with their help. TRIDEC and the local governments are also pursuing new leads leading to at least 70-90 additional local direct jobs. The overall community-wide impact of this effort would be an increase of about 1,440 total jobs and about $\$ 55$ million in total wage income in FY 1998.

When these jobs are added to the potential positive impacts of about 680 jobs due to agriculture and 425 jobs due to increases in regional services, and set against the effects of additional Hanford downsizing, FY 1998 should see a net increase of about 670 jobs over FY 1997. Similarly, as a result of the $\$ 55$ million in wage income due to new economic development, $\$ 14$ million in new wage income due to agriculture, and \$16 million in new wage incomes due to regional services, total local wage income should see a net increase of about $\$ 7$ million.

\section{Conclusion and Looking Ahead to FY 1999 and Beyond}

The diversification of the local economy is on track, but the challenges remain. As Hanford downsizing continues, the core Hanford budget is expected to continue to decline, slowly eliminating a major component of the Tri-Cities area's economic base. The local DOE budget request for FY 1999 is $\$ 1.8$ billion, of which $\$ 330$ million is expected to be set aside for privatization of high-level nuclear waste operations. The difference, $\$ 1.480$ billion, would represent a slight increase from FY 1998 in dollars available for current spending.

Two proposals for Phase I of the high-level waste privatization process are now under review. If the privatization effort goes forward, then one or both private contractor teams will be investing heavily (up to several billion dollars) with their own money and employing several hundred construction and operations workers at waste vitrification facilities at the Hanford Site beginning as early as 
late 1998 and continuing into the next century. The level and timing of these proposed investments is still extremely uncertain at this time. Waste privatization could provide a major short-run boost to the local economy, but it will be necessary in any case to develop a more permanent and more diverse economic base for the Tri-Cities area. Consequently, it is necessary for the community to continue and accelerate the diversification efforts which have shown success thus far. 


\section{INFORMATION CLEARANCE FORM}

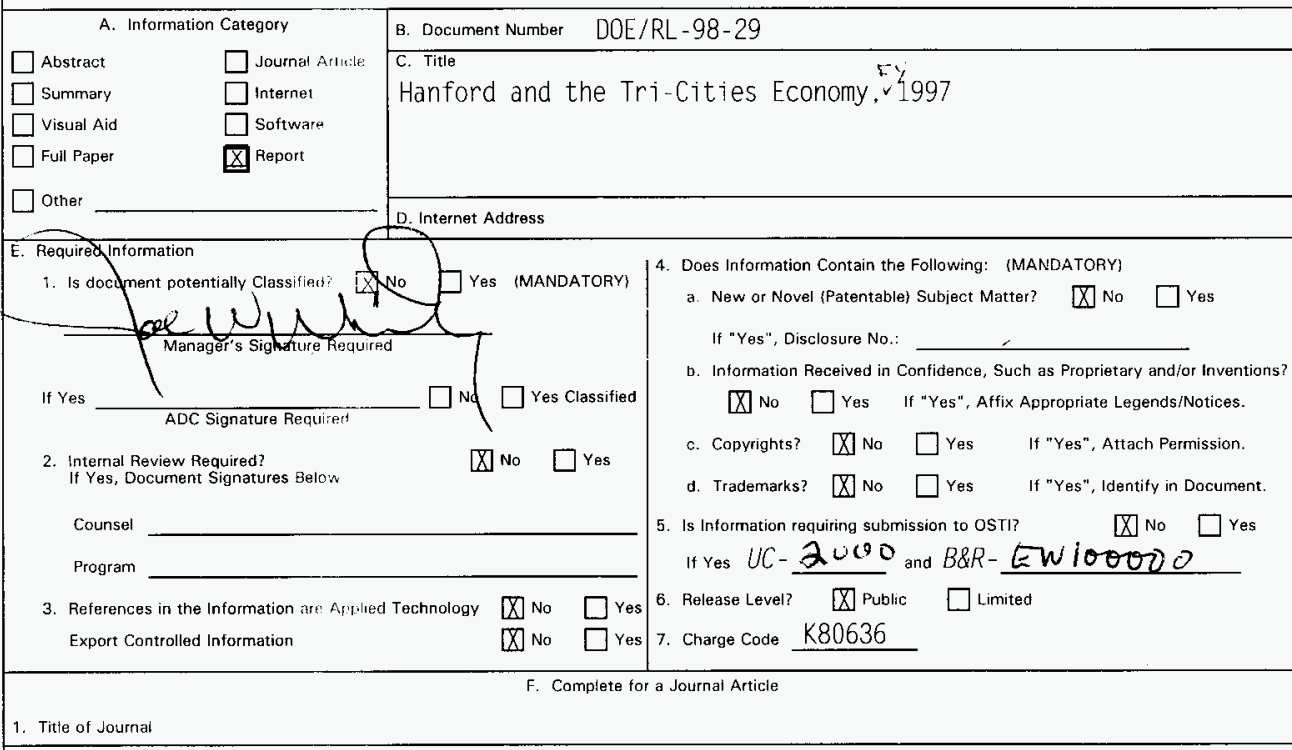

\section{G. Complete for a Presentation}

1. Title for Conference or Meeting

2. Group Sponsoring

3. Date of Conference

5. Will Information be Published in Procendings? $\square$ No $\square$ Yes

4. City/State

H. Author/Requestor

Mark Coronado (Print and Sign)

1. Reviewers
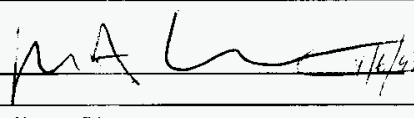

6. Will Material be Handed Out? $\square$ No

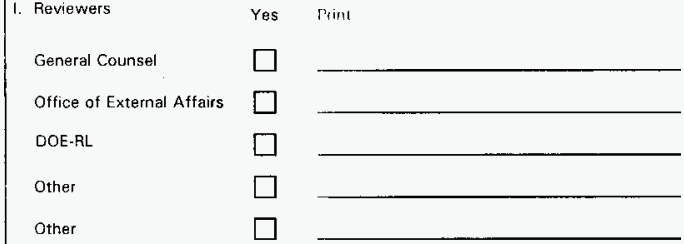
RësponsibTé Manager

J. If Information Includes Sensitive Informaticn and is not to be released to the Public indicate category below.

$\square$ Applied Technologv

$\square$ Promertind CRADA

$\square$ Personal/Private

$\square$ Expoi Controlled

$\square$ Proprietary

$\square$ Pror liement-Sensitive

$\square$ Business-Sensitive

$\square$ Patemilile

$\square$ Predecisiona!

$\square$ Other |Specify)

$\square$ UCNI

K. If Additional Comments, Please Attach Separate Sheet

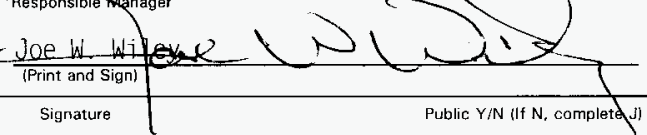
$Y / N$
$Y / N$
$Y / N$
$Y / N$
$Y / N$

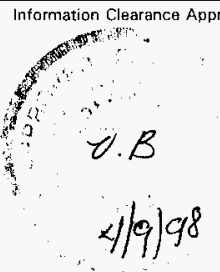

